\title{
Development of celiac disease-associated antibodies in offspring of parents with Type I diabetes
}

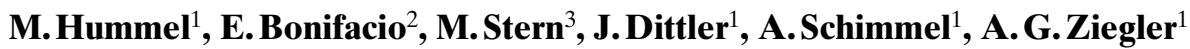 \\ ${ }^{1}$ Diabetes Research Institute and 3rd Medical Department, Academic Teaching Hospital München-Schwabing, Munich, Germany \\ ${ }^{2}$ Istituto Scientifico San Raffaele, Milan, Italy \\ ${ }^{3}$ University Children's Hospital, Tübingen, Germany
}

\begin{abstract}
Aims/hypothesis. The aim of this study was to determine the frequency and temporal development of antibodies related to celiac disease in offspring of parents with Type I (insulin-dependent) diabetes mellitus.

Methods. Sera from 913 offspring of parents with Type I diabetes prospectively followed from birth to the age of 8 years were tested for IgG-transglutaminase antibodies (IgG-tTGCAs), endomysial IgA antibodies (EMA) and gliadin antibodies.

Results. We found tTGCAs in 32 (3.5\%) of the 913 relatives. Prevalence was related to age and reached $6.5 \%$ at age 8 years. Endomysial IgA antibodies were detected in $44 \%$ of the relatives with tTGCAs and $0.6 \%$ of tTGCA negative relatives and were also most prevalent $(5 \%)$ in those aged 8 years. Both tTGCAs and EMAs were more frequent in relatives with the HLA DRB1*03 DQA1*0501 DQB1*02 haplotype $(7.1 \%$ and $7.2 \%$, respectively; $p<0.005)$. Antigliadin antibodies were common in both tTGCA positive $(42 \%)$ and negative $(23 \%)$ relatives, did not show
\end{abstract}

Celiac disease $(C D)$ is associated with the presence of antibodies to the endomysial antigen tissue transglutaminase C (tTGC) and the wheat protein gluten

Received: 20 January 2000 and in revised form: 26 April 2000

Corresponding author: , Prof. Dr. A.-G. Ziegler, Diabetes Research Institute, Koelner Platz 1, D-80804 Munich, Germany Abbreviations: CD: celiac disease, IEL: intra-epithelial lymphocytes, AGA: anti-gliadin antibody, EMA: endomysial IgA antibody, GADA: glutamic acid decarboxylase antibody, tTGCA: tissue transglutaminase $\mathrm{C}$ antibody. a relation with age and were less prevalent in relatives with HLA DR3 $(p<0.05)$. There was no association between the presence of antibodies associated with celiac disease and islet autoantibodies in these relatives. Of the relatives 15 (1.6\%) had tTGCAs plus EMAs. In two of these, anti-gliadin antibodies were detected before the detection of tTGCAs and EMAs at the age of 9 months whereas none of the remainder had any antibodies associated with celiac disease before age 2 years. In three there were no detectable antigliadin antibodies in any of the samples tested. Celiac disease without clinical symptoms was diagnosed in 9 of 12 by intestinal biopsy.

Conclusion/interpretation. A statistically significant proportion of relatives of patients with Type I diabetes have celiac disease-associated autoimmunity and the silent form of celiac disease early in life. These relatives should, therefore, be considered for celiac antibody screening. [Diabetologia (2000) 43: 10051011]

Keywords Celiac disease, Type I diabetes, transglutaminase, antibody screening, islet antibodies

$[1,2]$. These antibodies have been shown to be more prevalent in patients with Type I (insulin-dependent) diabetes mellitus than in the general population and their presence identifies people with silent or latent CD [3]. The increased prevalence in Type I diabetes is in part due to common HLA-risk alleles associated with diabetes and $\mathrm{CD}$ and possibly similar pathogenetic mechanisms $[4,5]$. Because relatives of patients with Type I diabetes also have an increased prevalence of these HLA-risk alleles, it is predictable that the prevalence of $\mathrm{CD}$ will also be increased in these subjects. Here we report antibodies related to celiac 


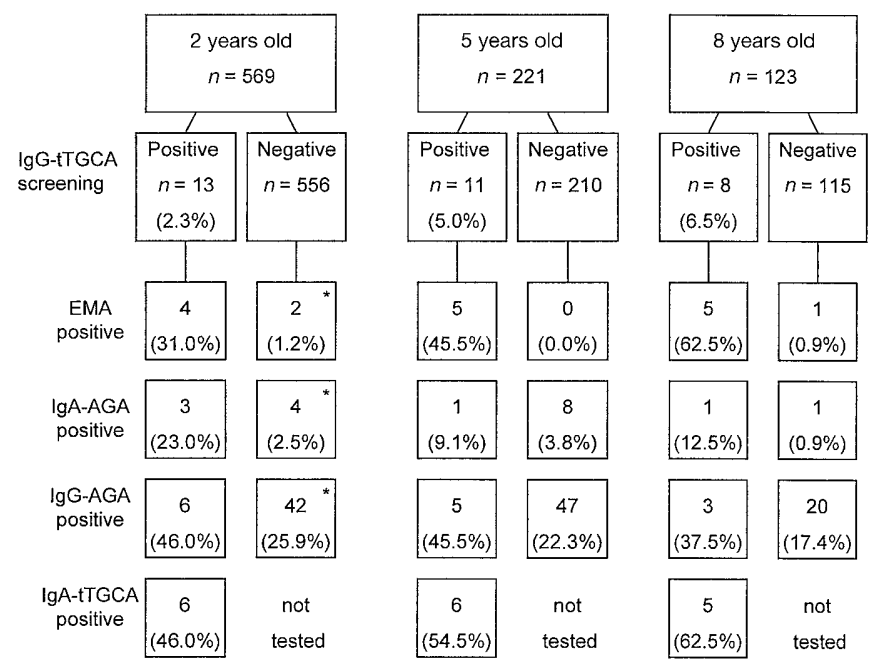

Fig. 1. Flow chart of antibodies associated with celiac disease in the BABYDIAB study cohort. Age given is at IgG-tTGCA screening. * only 163/555 IgG-TGCA negatives tested (nonselected)

disease in a cohort of over 900 offspring of parents with Type I diabetes in the German BABYDIAB study $[6,7]$. These offspring are followed from birth with samples for antibody measurement at 9 months, 2 years, 5 years and 8 years of age, for a prospective analysis of the temporal development of CD-associated antibodies and their disease relevance in a cohort that is at risk. The findings are presented in relation to HLA genotype and the development of diabetes-associated autoantibodies in the same cohort.

\section{Subjects and methods}

Subjects. The BABYDIAB study is an ongoing prospective German multicentre study that schedules offspring of parents with Type I diabetes for regular visits for venous blood sampling at birth (cord blood), at around 9 months, 2, 5 and 8 years of age [6]. All samples are routinely tested for diabetes-associated antibodies and additional samples are collected at 2 years of age for HLA DR and DQ allele typing. Here, antibodies associated with celiac disease [tissue transglutaminase $\mathrm{C}$ antibody (tTGCA), endomysial IgA antibody (EMA), anti-gliadin antibody (AGA)] and manifestation of CD were examined in this prospectively followed BABYDIAB cohort. The last available sample (569 at the age of 2 years, 221 at 5 years and 123 at the age of 8 years) from a total of 913 offspring (450 female, 463 male offspring) from 795 families (222 in which the father had Type I diabetes, 558 in which the mother had Type I diabetes, and 15 in which both parents had Type I diabetes) was tested for IgG-tTGCAs (Fig. 1). All the 123 offspring tested at 8 years, the 221 offspring tested at 5 years and 176 of those tested at 2 years were also screened for EMAs and AGAs ( $\mathrm{IgG}$ and $\operatorname{IgA}$ ). In offspring with increased levels of IgG-tTGCAs, EMAs or AGAs all available consecutive earlier samples were subsequently tested for IgG-tTGCAs, IgA-tTGCAs, EMAs, IgG-AGAs and IgA-AGAs. Missing values are due to insufficient samples remaining for testing. Offspring with EMAs and tTGCAs were asked to undergo an intestinal biopsy. Celiac disease was diag- nosed according to the criteria of the European Society for Paediatric Gastroenterology and Nutrition [8]. Celiac disease was not diagnosed in any of the 913 offspring before screening. We did HLA DR typing in $785(86 \%)$ and HLA-DQ typing in 776 (85\%) offspring [7]. Informed written consent for the testing of $\mathrm{CD}$ antibodies was obtained from the parents. The study was approved by the local ethics committee (No. 95357, Bavarian Medical Council).

Serum samples from 263 healthy subjects in the area of Munich (median age 30.4 years), including 71 children aged less than 8 years, served as controls. Sera from 99 subjects with newly diagnosed Type I diabetes (median age 11.4 years) were also tested for IgG-tTGCAs.

Measurement of tTGC-IgG and tTGC-IgA antibodies. Human tissue transglutaminase $\mathrm{C}$ cDNA in the pGEM-T-easy Vector (Promega, Madison, Wis., USA) was kindly provided by V. Lampasona, Milan, Italy. The tTGC cDNA was expressed as a ${ }^{35} \mathrm{~S}$-methionine labelled protein using the in vitro coupled transcription/translation protocol (Promega). Antibodies to tissue transglutaminase $\mathrm{C}$ were measured by radio-binding assay as described previously [9]. Briefly, $2 \mu \mathrm{l}$ of serum were added to $25 \mu \mathrm{l}$ of $50 \mathrm{mmol} / \mathrm{l}$ TRIS-HCl, $150 \mathrm{mmol} / \mathrm{l} \mathrm{NaCl}, 1 \%$ Tween $20 \mathrm{pH} 7.4$ containing $15,000 \mathrm{cpm}$ of tissue transglutaminase $\mathrm{C}$ in duplicate wells of 96 deep-well plates (Beckman, Fullertone, Calif., USA) and incubated overnight at $4{ }^{\circ} \mathrm{C}$. Antibody-bound label was isolated with protein-A Sepharose (Pharmacia, Uppsala, Sweden) for measurement of IgG antibodies and counted. For measurement of $\operatorname{IgA}$ antibodies protein-A Sepharose was replaced in the assay with $4 \mu \mathrm{l}$ of anti-IgA covalently bound to agarose beads (Sigma-Aldrich, St Louis, Mo., USA). Results for each assay were expressed as arbitrary units derived from standard curves of serial dilutions of a serum with both $\mathrm{IgG}$ and IgA tTGCAs tested in each assay. The mean + 3SD of results for the 263 control subjects corresponded to 2.4 units for the IgG-tTGCA. The mean +3 SD of the 71 control children below age 8 years was 2.5 units and was used as the threshold for positivity in the screening assay.

Measurement of EMA and $\operatorname{Ig} A$ and $\operatorname{Ig} G A G A$. The IgA EMAs (by indirect immunofluorescence on human umbilical cord) and $\operatorname{IgA}$ and IgG AGAs (ELISA) were measured in Tübingen in M. Stern's laboratory as described previously [10]. The EMA assay achieved a sensitivity of $93 \%$, a specificity of $99 \%$ and a interrater-reliability kappa of 0.988 , the IgA AGA $90 \%, 75 \%$ and 0.730 and the IgG AGA $91 \%, 70 \%$ and 0.920 , respectively (EMRC/ESPGHAN Working Group, Serological Screening for CD, 1998, Protocol $5^{\text {th }}$ Workshop. Ring Test Data. Protocol Trieste). The threshold for IgA AGA ELISA was 0.034, and for the IgG AGA ELISA it was 0.087 . For the detection of IgG-EMAs a fluorescein isothiocyanate conjugated (FITC) goat and rabbit anti-IgG antibody (DiaSorun, Stillwater, Minn., USA) was used.

HLA typing. The HLA-DR and HLA-DQ alleles were analysed using PCR-amplified DNA and non-radioactive sequence-specific oligonucleotide (SSO) probes as described previously [7]. The alleles DQB1*0201 and DQB1*0202 were indistinguishable by SSO and were referred to as DQB1*02.

Statistical analysis. Differences in antibody levels were calculated by Mann-Whitney U test and differences in frequencies by chi-squared analysis or Fisher's exact test. Correlation of antibody levels with age was calculated by the Kruskall-Wallis test. We considered $p$ values less than 0.05 as significant. The Statistical Package for Social Sciences (SPSS 8.0.1, Chicago, Il, USA) was used for all statistical analysis. 


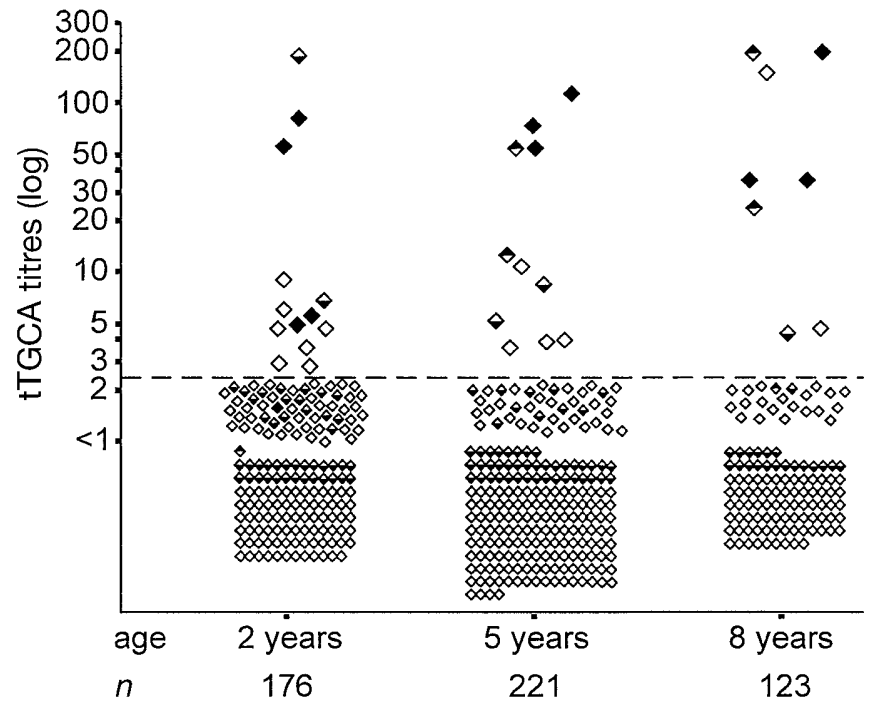

Fig. 2. Scatter plot of units obtained in the IgG-tTGCA assay in sera from 520 offspring of parents with Type I diabetes at 2, 5 , and 8 years of age in whom IgG-tTGCAs, EMAs and AGAs were tested. The threshold for positivity for the IgGtTGCA is indicated by the broken line. Samples with EMA $(\boldsymbol{\Delta})$ and IgG-AGA or IgA-AGA ( $\boldsymbol{\nabla})$ positive titres are indicated with filled triangles

\section{Results}

Tissue transglutaminase $C$ antibodies (tTGCA). We detected IgG-tTGCAs in $32(3.5 \%)$ of the 913 offspring of parents with Type I diabetes, $2(0.7 \%)$ of the control subjects (1.3\% of the 71 control children) and $10(10.1 \%)$ of the patients with newly diagnosed Type I diabetes. The prevalence in offspring was $2.3 \%$ in those tested at age 2 years, $5.0 \%$ at age 5 years and $6.5 \%$ at age 8 years $\left(p<0.05, \chi^{2}\right.$ test for trend; Fig.1). Titres of tTGCA also increased with age $(p<0.05$; Fig. 2). We found IgA-tTGCA in 17 of the 32 offspring with IgG-tTGCA, including 12 of the 15 offspring with an IgG-tTGCA titre more than 10 units.
Anti-gliadin antibodies and EMAs. We detected EMAsin 14 (43.8\%) of 32 offspring with IgG-tTGCAs and $3(0.6 \%)$ of 488 offspring without IgG-tTGCAs $(p<0.001)$ and they were most prevalent $(80 \%)$ in offspring with more than 10 units of IgG-tTGCAs (Fig. 2). Their overall prevalence in non-selected offspring tested at age 5 and 8 years was $3.2 \%(11 / 344)$, and this tended to be higher in older offspring $(2.3 \%$ at 5 years vs $4.9 \%$ at 8 years; NS). Anti-gliadin antibodies, especially IgG-AGAs were frequent and were also more prevalent in offspring with IgG-tTGCAs (IgA-AGA $14.7 \%$ vs $2.7 \%, p=0.02$; IgG-AGA $41.2 \%$ vs $22.4 \%, p=0.05)$. In contrast to tTGCA and EMA, the prevalence of AGA showed a tendency to decrease with age (Fig.1).

Antibody combinations. A total of 520 offspring were tested for IgG-tTGCAs, EMAs and AGAs. Of these, 148 had CD-associated antibodies in at least one antibody test (Table 1 ). The majority (118 offspring) were positive in only one test and this was usually the IgG-AGA test (100 offspring). A further 8 were positive for both IgG-AGAs and IgA-AGAs only, and 2 for IgG-tTGCAs and IgA-tTGCAs only. The remaining 20 offspring had at least two of the tTGCAs, EMAs or AGAs, including 10 with all 3 antibodies (1 having IgG-tTGCA, IgG-AGA, IgG-EMA and $\operatorname{IgA}$ deficiency) and 5 with high titres of $\operatorname{IgG}$ and IgA-tTGCA and EMA, but no detectable AGA. Of the 15 offspring with tTGCAs and EMAs 11 were female and females had a higher prevalence of EMA plus tTGCA than males $(4.5 \%$ vs $0.9 \%$; $p<0.01)$.

HLA and antibodies associated with CD in offspring. The tTGCAs were more prevalent in offspring with HLA DQA1*0501 DQB1*02 containing genotypes $(19 / 269,7.1 \%)$ than non-DQA1*0502 DQB $1 * 02$ offspring $(10 / 506,2.0 \% ; p=0.003)$ and in offspring with DRB1*03 containing genotypes $(7.2 \%$ vs $2.3 \% ; p=0.002)$. Offspring with the $\mathrm{DRB}^{*} 03$

Table 1. Frequency of CD-related antibody combinations in 520 offspring of parents with Type I diabetes

\begin{tabular}{|c|c|c|c|c|c|c|}
\hline & EMA & tTGCA-IgG & tTGCA-IgA & AGA-IgG & AGA-IgA & $n(\%)$ \\
\hline 0 test positive & - & - & - & - & - & $372(71.4)$ \\
\hline 1 test positive & $\begin{array}{l}+ \\
- \\
- \\
-\end{array}$ & $\begin{array}{l}- \\
+ \\
- \\
-\end{array}$ & $\begin{array}{l}- \\
- \\
- \\
-\end{array}$ & $\begin{array}{l}- \\
- \\
+ \\
-\end{array}$ & $\begin{array}{l}- \\
- \\
- \\
+\end{array}$ & $\begin{array}{r}2(0.4) \\
11(2.1) \\
100(19.2) \\
5(1.0)\end{array}$ \\
\hline 2 tests positive & $\begin{array}{l}+ \\
- \\
- \\
-\end{array}$ & $\begin{array}{l}- \\
+ \\
- \\
+\end{array}$ & $\begin{array}{l}- \\
+ \\
- \\
-\end{array}$ & $\begin{array}{l}+ \\
- \\
+ \\
+\end{array}$ & $\begin{array}{l}- \\
- \\
+ \\
-\end{array}$ & $\begin{array}{l}1(0.2) \\
2(0.4) \\
8(1.5) \\
4(0.8)\end{array}$ \\
\hline 3 tests positive & + & + & + & - & - & $5(1.0)$ \\
\hline 4 tests positive & $\begin{array}{l}+ \\
-\end{array}$ & $\begin{array}{l}+ \\
+\end{array}$ & $\begin{array}{l}+ \\
+\end{array}$ & $\begin{array}{l}+ \\
+\end{array}$ & $\begin{array}{l}- \\
+\end{array}$ & $\begin{array}{l}5(1.0) \\
1(0.2)\end{array}$ \\
\hline 5 tests positive & + & + & + & + & + & $4(0.8)$ \\
\hline
\end{tabular}




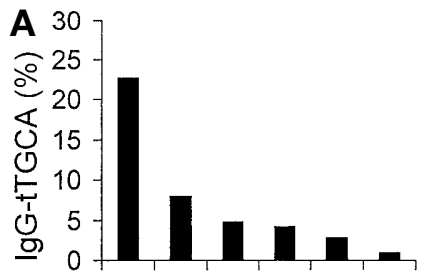

DR $3 / 3 \quad 3 / 4 \quad 3 / \times \quad 4 / 4 \quad 4 / X \quad X / X$

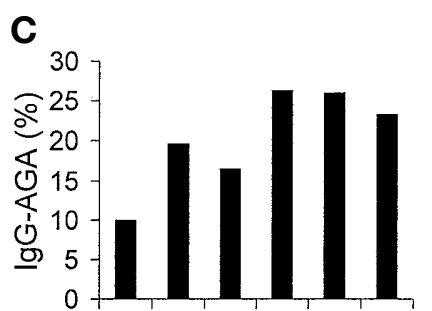

DR $3 / 3 \quad 3 / 4 \quad 3 / \mathrm{X} \quad 4 / 4 \quad 4 / \mathrm{X} \quad \mathrm{X} / \mathrm{X}$

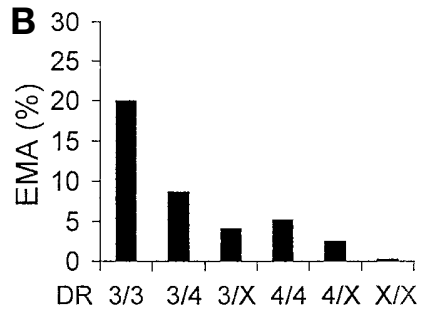

D

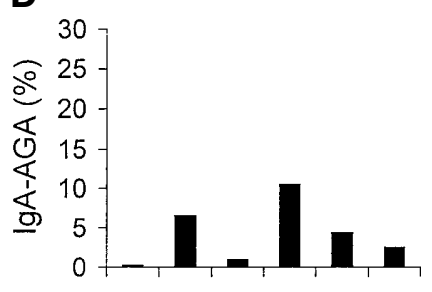

Fig.3 a-d. Prevalence of IgG-tTGCA (A), EMA (B), IgGAGA $(\mathbf{C})$, and IgA-AGA (D) with respect to HLA DR genotype in the BABYDIAB subjects $(\mathbf{A}, n=784 ; \mathbf{B}-\mathbf{D}, n=453)$. $\mathrm{X}$ are alleles other than DRB1*03 and DRB1*04

DQA*0501 DQB*02/DRB*03 DQA*0501 DQB*02 genotype had the highest prevalence of tTGCA $(22.7 \%)$ and this was increased over that of offspring heterozygous for DRB1*03 DQA1*0501 DQB1*02 $(p=0.01$, Fig.3). Similarly, EMAs were also increased in offspring with HLA DQA $1 * 0501$ DQB1 $* 02(6.5 \%$ vs $1.7 \% ; p=0.01)$ and in offspring with DRB1*03 (6.5\% vs $1.7 \% ; p=0.01)$. Of the 15 offspring with both tTGCAs and EMAs, $12(80 \%)$ had HLA DRB1*03 DQA1*0501 DQB1*02 and the remaining 3 had HLA DRB1*04 DQA1*0301 DQB1*0302. In contrast, AGAs were less prevalent in offspring positive for DQA1*0502 DQB1*02 $(p<0.05)$ or DRB1*03 $(p<0.05)$. Moreover, none of 8 with both IgG-AGAs and IgA-AGAs and no tTGCAs or EMAs had DQA1*0502 DQB1*02 or DRB1*03.

Chronology of CD antibody development. Consecutive samples from 15 offspring positive for both tTGCA and EMA showed that 8 offspring developed tTGCAs and EMAs in their 2-year sample, another 4 developed these antibodies in their 5-year sample and in 2 offspring, they were detected first in their 8year sample (Table 2). The remaining offspring with tTGCAs and EMAs no longer had samples available before the first measurement at age 8 years. The tTGCAs and EMAs appeared together and were never detected before the 2-year sample. There were 11 offspring who also developed AGAs. In three offspring weak IgG-AGAs could be detected at 1.0, 1.0, and 2.1 years of age and before tTGCAs and EMAs, and in the remaining 8 offspring AGAs were first detected at or later than 2 years of age and together with EMAs and tTGCAs. Samples at birth were available and tested in 12 of these 15 offspring and no CD-associated antibodies were detected. One offspring who had tTGCAs, EMAs (IgG and IgA) and IgG-AGAs at age 2 years did not have detectable $\mathrm{CD}$-associated antibodies at age 2.9 years.

Biopsies were done between age 2.0 and 8.5 years in 12 of the offspring with tTGCAs and EMAs. Celiac disease was diagnosed in 9 and 2 others had greater numbers of intra-epithelial lymphocytes (IEL). Only one of these (case no. 9) had clinical symptoms of CD.

Relation between antibodies associated with $C D$ and islet autoantibodies. Confirmed positivity for at least one diabetes-associated autoantibody (insulin autoantibodies, GADA, antibodies against the tyrosine-phosphatase IA-2, islet cell antibodies) was detected in $42(4.6 \%)$ of the 913 offspring. The tTGCAs were found in similar prevalence in those with $(4.8 \%)$ or without $(3.6 \%)$ diabetes-associated antibodies. Of the 15 offspring with tTGCAs and EMAs 1 also had diabetes-associated antibodies (case no. 6 GADA +) which became undetectable after she started a gluten-free diet (data not shown) and 1 of these offspring (case no. 10) had a sibling with multiple islet autoantibodies.

\section{Discussion}

The overall prevalence of IgG-tTGCAs in offspring of patients with Type I diabetes was statistically significantly higher than in healthy control subjects and in the older offspring approached that in patients with Type I diabetes. The prevalence of both tTGCAs and EMAs in the offspring correlated with age suggesting a relation with the duration of gluten exposure [11]. By age 5 years $3 \%$ of all offspring were both tTGCA and EMA positive and although only one offspring had clinical symptoms, the presence of these markers was usually associated with CD proved by biopsy. The predominance of the silent form of $C D$ in the offspring is similar to that reported in patients with Type I diabetes [4,12,13]. We suggest, therefore, that screening for CD should not only be done in patients with Type I diabetes but also extended to their first-degree relatives. Screening in these relatives could be combined with that for Type I diabetes-associated autoantibodies [14].

The presence of $\mathrm{CD}$-associated autoimmunity was more prevalent in female offspring and in offspring with the HLA DRB1*03 DQA1*05 DQB1*02 (DR3-DQ2) haplotype. This is consistent with the previously reported female predominance in patients having both Type I diabetes and CD [4] and the association of HLA DR3 and DQ2 with CD [15] and tTGCAs [16]. As found in patients with Type I diabetes [16], relatives who were homozygous for the DR3- 
Table 2. Chronology of CD antibody development in offspring with EMAs and tTGCAs

\begin{tabular}{|c|c|c|c|c|c|c|c|c|}
\hline $\begin{array}{l}\text { case no. } \\
\text { sex }\end{array}$ & $\begin{array}{r}\text { HLA -DR } \\
\text {-DQA } \\
\text {-DQB }\end{array}$ & $\begin{array}{l}\text { age } \\
\text { (years) }\end{array}$ & $\begin{array}{l}\text { tTGCA } \\
\text { IgG }\end{array}$ & $\begin{array}{l}\text { tTGCA } \\
\text { IgA }\end{array}$ & $\begin{array}{l}\text { EMA } \\
\text { IgA }\end{array}$ & $\begin{array}{l}\text { AGA } \\
\text { IgG }\end{array}$ & $\begin{array}{l}\text { AGA } \\
\text { IgA }\end{array}$ & $\begin{array}{l}\text { biopsy/ } \\
\text { comments }\end{array}$ \\
\hline $\begin{array}{l}\text { No. } 1 \\
\text { female }\end{array}$ & $\begin{array}{l}\text { DR 02/03 } \\
\text { DQA 0102/05 } \\
\text { DQB 0502/02 }\end{array}$ & $\begin{array}{l}1.9 \\
7.6\end{array}$ & $\begin{array}{l}- \\
+++\end{array}$ & $\begin{array}{l}- \\
+++\end{array}$ & $\begin{array}{r}0 \\
200\end{array}$ & - & - & $\mathrm{CD}$ \\
\hline $\begin{array}{l}\text { No. } 2 \\
\text { female }\end{array}$ & $\begin{array}{l}\text { DR 02/03 } \\
\text { DQA 0102/05 } \\
\text { DQB 0502/02 }\end{array}$ & $\begin{array}{l}0.8 \\
1.9 \\
5.0 \\
7.6\end{array}$ & $\begin{array}{l}- \\
- \\
+++ \\
++\end{array}$ & $\begin{array}{l}- \\
- \\
+++ \\
+++\end{array}$ & $\begin{array}{r}0 \\
0 \\
100 \\
100\end{array}$ & $\begin{array}{l}- \\
- \\
- \\
-\end{array}$ & $\begin{array}{l}- \\
- \\
- \\
-\end{array}$ & $\begin{array}{l}\text { case no. } 1 \text { and no. } 2 \\
\text { are identical twins } \\
\text { CD }\end{array}$ \\
\hline $\begin{array}{l}\text { No.3 } \\
\text { female }\end{array}$ & $\begin{array}{l}\text { DR 0401/13 } \\
\text { DQA 03/0103 } \\
\text { DQB 0302/0603 }\end{array}$ & $\begin{array}{l}1.0 \\
1.9 \\
4.8 \\
5.5\end{array}$ & $\begin{array}{l}- \\
- \\
- \\
+++\end{array}$ & $\begin{array}{l}- \\
- \\
- \\
++\end{array}$ & $\begin{array}{r}0 \\
0 \\
0 \\
200\end{array}$ & $\begin{array}{l}+ \\
+ \\
- \\
+\end{array}$ & $\begin{array}{l}- \\
- \\
- \\
-\end{array}$ & $\mathrm{CD}$ \\
\hline $\begin{array}{l}\text { No. } 4 \\
\text { female }\end{array}$ & $\begin{array}{l}\text { DR } 03 / 03 \\
\text { DQA 05/05 } \\
\text { DQB 02/02 }\end{array}$ & $\begin{array}{l}1.0 \\
2.0 \\
5.5\end{array}$ & $\begin{array}{l}- \\
++ \\
+\end{array}$ & $\begin{array}{l}- \\
+++ \\
++\end{array}$ & $\begin{array}{r}0 \\
400 \\
100\end{array}$ & $\begin{array}{l}- \\
- \\
-\end{array}$ & $\begin{array}{l}- \\
++ \\
-\end{array}$ & $\mathrm{CD}$ \\
\hline $\begin{array}{l}\text { No. } 5 \\
\text { female }\end{array}$ & $\begin{array}{l}\text { DR 04/13 } \\
\text { DQB 0302/0604 }\end{array}$ & $\begin{array}{l}0.8 \\
2.4 \\
5.0\end{array}$ & $\begin{array}{l}- \\
++ \\
++\end{array}$ & $\begin{array}{l}- \\
++ \\
+++\end{array}$ & $\begin{array}{r}0 \\
100 \\
100\end{array}$ & $\begin{array}{l}- \\
++ \\
+++\end{array}$ & $\begin{array}{l}- \\
+ \\
+++\end{array}$ & $\mathrm{CD}$ \\
\hline $\begin{array}{l}\text { No. } 6 \\
\text { female }\end{array}$ & $\begin{array}{l}\text { DR 03/0401 } \\
\text { DQA 05/03 } \\
\text { DQB 02/0302 }\end{array}$ & $\begin{array}{l}2.5 \\
4.5 \\
8.5\end{array}$ & $\begin{array}{l}- \\
- \\
+++\end{array}$ & $\begin{array}{l}- \\
- \\
++\end{array}$ & $\begin{array}{r}0 \\
0 \\
200\end{array}$ & $\begin{array}{l}- \\
- \\
++\end{array}$ & $\begin{array}{l}- \\
- \\
-\end{array}$ & $\begin{array}{l}\text { islet autoantibody } \\
\text { (GADA) + } \\
\text { CD }\end{array}$ \\
\hline $\begin{array}{l}\text { No. } 7 \\
\text { female }\end{array}$ & $\begin{array}{l}\text { DR 03/0401 } \\
\text { DQA 05/03 } \\
\text { DQB 02/0302 }\end{array}$ & 8.5 & +++ & +++ & 800 & ++ & +++ & $\mathrm{CD}$ \\
\hline $\begin{array}{l}\text { No. } 8 \\
\text { female }\end{array}$ & $\begin{array}{l}\text { DR } 03 / 0403 \\
\text { DQA } 05 / 03 \\
\text { DQB } 02 / 0302\end{array}$ & $\begin{array}{l}0.7 \\
2.0\end{array}$ & $\begin{array}{l}- \\
+\end{array}$ & $\begin{array}{l}- \\
+++\end{array}$ & $\begin{array}{r}0 \\
400\end{array}$ & $\begin{array}{l}- \\
+++\end{array}$ & $\begin{array}{l}- \\
+++\end{array}$ & $\mathrm{CD}$ \\
\hline $\begin{array}{l}\text { No. } 9 \\
\text { female }\end{array}$ & $\begin{array}{l}\text { DR 01/03 } \\
\text { DQA 0101/05 } \\
\text { DQB 0501/02 }\end{array}$ & $\begin{array}{l}0.8 \\
2.1 \\
4.5\end{array}$ & $\begin{array}{l}- \\
- \\
++\end{array}$ & $\begin{array}{l}- \\
- \\
+\end{array}$ & $\begin{array}{r}0 \\
0 \\
50\end{array}$ & $\begin{array}{l}- \\
+ \\
+\end{array}$ & $\begin{array}{l}- \\
- \\
-\end{array}$ & $\begin{array}{l}\text { abdominal pain and } \\
\text { frequent bowel } \\
\text { movement; biopsy: } \\
\text { increased IEL }\end{array}$ \\
\hline $\begin{array}{l}\text { No. } 10 \\
\text { female }\end{array}$ & $\begin{array}{l}\text { DR 0401/0404 } \\
\text { DQA 03/03 } \\
\text { DQB 0302/0302 }\end{array}$ & $\begin{array}{l}1.0 \\
2.3 \\
4.8 \\
7.6\end{array}$ & $\begin{array}{l}- \\
- \\
+ \\
++\end{array}$ & $\begin{array}{l}- \\
- \\
- \\
+++\end{array}$ & $\begin{array}{r}0 \\
0 \\
50 \\
5\end{array}$ & $\begin{array}{l}- \\
- \\
- \\
-\end{array}$ & $\begin{array}{l}- \\
- \\
- \\
-\end{array}$ & $\begin{array}{l}\text { brother with multi- } \\
\text { ple islet autoantibo- } \\
\text { dies } \\
\text { biopsy: negative }\end{array}$ \\
\hline $\begin{array}{l}\text { No. } 11 \\
\text { female }\end{array}$ & $\begin{array}{l}\text { DR 02/03 } \\
\text { DQA 0102/05 } \\
\text { DQB 0602/02 }\end{array}$ & $\begin{array}{l}0.8 \\
2.5\end{array}$ & $\begin{array}{l}- \\
+\end{array}$ & $\begin{array}{l}- \\
+++\end{array}$ & $\begin{array}{r}0 \\
400\end{array}$ & $\begin{array}{l}- \\
+\end{array}$ & - & $\mathrm{CD}$ \\
\hline $\begin{array}{l}\text { No. } 12 \\
\text { male }\end{array}$ & $\begin{array}{l}\text { DR } 03 / 03 \\
\text { DQA 05/05 } \\
\text { DQB 02/02 }\end{array}$ & $\begin{array}{l}0.8 \\
2.0 \\
2.9\end{array}$ & $\begin{array}{l}- \\
++ \\
-\end{array}$ & $\begin{array}{l}- \\
+ \\
-\end{array}$ & $\begin{array}{l}0 \\
5 \\
0\end{array}$ & $\begin{array}{l}- \\
+ \\
-\end{array}$ & $\begin{array}{l}- \\
- \\
-\end{array}$ & \\
\hline $\begin{array}{l}\text { No. } 13 \\
\text { male }\end{array}$ & $\begin{array}{l}\text { DR 01/03 } \\
\text { DQA 0101/05 } \\
\text { DQB 0501/02 }\end{array}$ & $\begin{array}{l}0.8 \\
2.5 \\
4.5\end{array}$ & $\begin{array}{l}- \\
+ \\
++\end{array}$ & $\begin{array}{l}- \\
+++ \\
++\end{array}$ & $\begin{array}{r}0 \\
100 \\
5\end{array}$ & $\begin{array}{l}- \\
- \\
-\end{array}$ & $\begin{array}{l}- \\
- \\
-\end{array}$ & \\
\hline $\begin{array}{l}\text { No. } 14 \\
\text { male }\end{array}$ & $\begin{array}{l}\text { DR } 03 / 0401 \\
\text { DQA } 05 / 03 \\
\text { DQB } 02 / 0302\end{array}$ & $\begin{array}{l}0.8 \\
2.2\end{array}$ & $\begin{array}{l}- \\
++\end{array}$ & $\begin{array}{l}- \\
+++\end{array}$ & $\begin{array}{r}0 \\
100\end{array}$ & $\begin{array}{l}- \\
++\end{array}$ & $\begin{array}{l}- \\
++\end{array}$ & \\
\hline $\begin{array}{l}\text { No. } 15 \\
\text { male }\end{array}$ & $\begin{array}{l}\text { DR 03/07 } \\
\text { DQA 05/0201 } \\
\text { DQB 02/02 }\end{array}$ & $\begin{array}{l}1.0 \\
2.5\end{array}$ & $\begin{array}{l}- \\
+++\end{array}$ & - & $\begin{array}{l}0 \\
0\end{array}$ & $\begin{array}{l}+ \\
+++\end{array}$ & $\begin{array}{l}- \\
-\end{array}$ & $\begin{array}{l}\text { IgA-deficiency, } \\
\text { EMA-IgG positive; } \\
\text { thyroid antibodies; } \\
\text { biopsy: elevated IEL }\end{array}$ \\
\hline
\end{tabular}

,+++ , and +++ correspond to IgG AGA levels of $0.087-0.2,0.2-0.8$ and $\geq 0.8$; IgA AGA levels of 0.034-0.05, 0.05-0.1 and $\geq 0.1$, IgG and IgA tTGCA levels of 2.4-20, 20-100 and > 100 
DQ2 haplotype had a particularly high risk for developing tTGCAs $(23 \%)$ and EMAs $(20 \%)$. This predisposition to coeliac-associated autoimmunity suggests mucosal-mediated immunoregulatory defects in subjects with the DR3-DQ2 haplotype which could act in the pathogenesis of coeliac disease and Type I diabetes. In contrast to the strong HLA association of tTGCA, AGA showed no association with the CD-associated HLA alleles. The IgG AGAs were relatively frequent and their presence as well as that of IgA AGAs in the absence of tTGCAs or EMAs was negatively associated with HLA DR3. This observation is remarkable in that it suggests that gliadin immunity as such can occur regardless of HLA and that progression to autoimmunity requires $\mathrm{CD}$-associated HLA alleles for the presentation of tTGC or tTGC-gliadin complexes. Notably, two relatives who developed CD had tTGCAs and EMAs, but no evidence of gliadin immunity in any of the samples tested from birth. Although we cannot exclude the presence of gliadin immunity in their mucosa, the absence of AGA in the clinical course of these patients could indicate that other antigens are involved in the pathogenesis of $\mathrm{CD}$.

A comparison to the clinical course of diabetesassociated autoimmunity in the same offspring [6] shows that $\mathrm{CD}$-associated autoimmunity occurs later and more rapidly. Although islet autoantibodies were found as early as in the first year of life, tTGCAs and EMAs were never detected before the 2-year sample and only a minority of those developing these autoantibodies had AGAs at age 1 year. Moreover, AGAs, EMAs and tTGCAs when found, were usually first detected simultaneously, indicating that the development of both immunity and autoimmunity in CD occurs quickly. As found in a cohort of school children from Sardinia [17], there was no relation between the appearance of diabetes-associated antibodies and tTGCAs in the BABYDIAB relatives suggesting that the increased risk of relatives of patients with Type I diabetes for developing CD-related autoimmunity is predominantly due to the common genetic susceptibility. Of note is, however, that one child with autoimmunity associated with both diabetes and CD became islet autoantibody negative after starting a glutenfree diet. As a transient islet autoimmunity is uncommon in these offspring [6], we cannot exclude that the humoral expression of islet autoimmunity is affected by gluten exposure in some subjects.

Apart from gluten exposure, CD has also been suggested to be linked with the duration of breastfeeding and the time of exposure to cows' milk [18]. This has also been suggested for Type I diabetes [19, 20]. We have previously found no association between breastfeeding duration and the development of islet autoantibodies in the BABYDIAB cohort [21] and here there was also no difference in total and exclusive breastfeeding duration between off- spring with or without autoimmunity to tTGCAs (data not shown). Breastfeeding could, however, be related to the age of manifestation of CD because breastfeeding duration was found in one study to be correlated to the age of CD onset [18].

Our study identifies a statistically significant proportion of relatives of patients with Type I diabetes who have autoimmunity associated with celiac disease and the silent form of celiac disease early in life. This autoimmunity was typically associated with HLA DR3/DQ2, and usually distinct from, and later than autoimmunity associated with Type I diabetes which in the same relatives was strongly associated with HLA DR4/DQ8 [7]. Screening for antibodies associated with $\mathrm{CD}$ should therefore be considered not only in patients with Type I diabetes, but also their relatives.

Acknowledgements. Grant support: This work was supported by grants from the German Celiac Society and the German Ministry for Research, Education and Technology (BMBF 01KD89030 and 1KD9601). We thank H. Naserke, M. Schenker, S. Schmid and I. Wäscher for expert technical assistance and E. Keller and E. Albert for HLA-typing (Immunogenetic Institute, University Munich). A. Bürgin-Wolff (Celiac Disease Diagnosis Laboratory, Liestal, Switzerland) kindly provided sera from $C D$ patients to establish the tTGCA assays. We also thank all obstetric departments, paediatricians and family doctors in Germany that participated in the trial for the recruitment and follow-up of families in BABYDIAB (named in ref. 7). This study forms part of the dissertation of J. Dittler and S. Schmid.

\section{References}

1. Dieterich W, Laag E, Schöpper H et al. (1998) Autoantibodies to tissue transglutaminase as predictors of celiac disease. Gastroenterology 115: 1317-1321

2. Sulkanen S, Halttunen T, Laurila K et al. (1998) Tissue transglutaminase autoantibody enzyme-linked immunosorbent assay in detecting celiac disease. Gastroenterology 115: $1322-1328$

3. Lampasona V, Bonfanti R, Bazzigaluppi E et al. (1999) Antibodies to tissue transglutaminase $\mathrm{C}$ in Type I diabetes. Diabetologia 42: 1195-1198

4. Cronin CC, Shanahan F (1997) Insulin-dependent diabetes mellitus and coeliac disease. Lancet 349: 1096-1097

5. Bonifacio E, Ziegler AG, Hummel M, et al. (1998) Gluten: is it also a determinant of islet autoimmunity? Diabetes Metab Rev 24: 259-260

6. Ziegler AG, Hummel M, Schenker M, Bonifacio E (1999) Autoantibody appearance and risk for the development of childhood diabetes in offspring of parents with Type I diabetes: the German BABY-DIAB study. Diabetes 48: 460-468

7. Schenker M, Hummel M, Ferber K et al. (1999) Early expression and high prevalence of anti-islet autoantibodies for DR3/4 heterozygous and DR4/4 homozygous offspring of parents with Type I diabetes: the German BABYDIAB study. Diabetologia 42: 671-677

8. The Working Group of the European Society for Paediatric Grastroenterology and Nutrition (1990) Revised criteria for diagnosis of coeliac disease. Arch Dis Child 65: 909-911 
9. Bazzigaluppi E, Lampasona V, Barera G et al. (1999) Comparison of tissue transglutaminase-specific antibody assays with established antibody measurements for coeliac disease. J Autoimmun 12: 51-56

10. Stern M, Teuscher M, Wechmann T (1996) Serological screening for coeliac disease: methological standards and quality control. Acta Paediatr Suppl 412: 49-51

11. Ventura A, Magazzu G, Greco L, SIGEP Study Group (1999) Duration of exposure to gluten and risk for autoimmune disorders in patients with celiac disease. Gastroenterology 117: 297-303

12. Mäki M, Huupponen T, Holm K, Hällström O (1995) Seroconversion of reticulin antibodies predict coeliac disease in insulin dependent diabetes mellitus. Gut 36: 239-242

13. Vitoria JC, Castano L, Rica I, Bilbao JR, Arrieta A, Garcia-Masdevall MD (1998) Association of insulin-dependent diabetes mellitus and celiac disease: a study based on serological markers. J Pediatr Gastroenterol Nutr 27: 47-52

14. Lampasona V, Bazzigaluppi E, Barera G, Bonifacio E (1998) Tissue transglutaminase and combined screening for coeliac disease and Type I diabetes-associated autoantibodies. Lancet 352: 1192-1193
15. Trier JC (1991) Celiac sprue. N Engl J Med 325: 1709-1719

16. Bao F, Yu L, Babu S et al. (1999) One third of HLA DQ2 homozygous patients with Type I diabetes express celiac disease-associated transglutaminase autoantibodies. J Autoimmun 13: 143-148

17. Meloni G, Dore A, Fanciulli G, Tanda F, Bottazzo GF (1999) Subclinical coeliac disease in schoolchildren from northern Sardinia. Lancet 353: 37

18. Mäki M, Holm K (1990) Incidence and prevalence of celiac disease in Tampere. Acta Paediatr Scand 79: 980-982

19. Virtanen SM, Räsänen L, Ylönen K et al. (1993) Early introduction of diary products associated with increased risk of IDDM in finish children. Diabetes 42: 1789-1793

20. Gerstein HC (1994) Cow's milk exposure and Type I diabetes mellitus: a critical review of the clinical literature. Diabetes Care 17: 13-19

21. Hummel M, Schenker M, Ziegler AG (1998) Appearance of diabetes-associated antibodies in children of diabetic parents is independent from environmental factors. Diabetologia [Suppl 1] 41: A91 